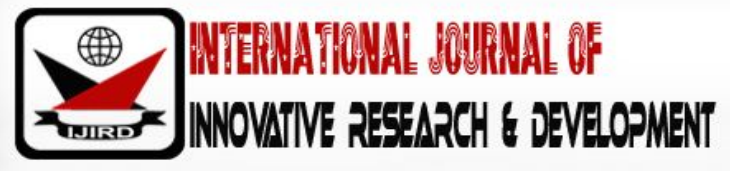

ISSN 2278 - 0211 (Online)

\section{Tax Incentive as a Tool for Marginal Field Development in Nigeria}

Jerome Okoro
Research Fellow, Center for Petroleum, Department of Energy Economics and Law,
University of Ibadan, Nigeria
P. C. Obutte
Senior Lecturer, Department of Jurisprudence, Faculty of Law, University of Ibadan, Nigeria
Deputy Director, University of Ibadan, Nigeria

\section{Abstract:}

This paper examines the role of tax incentives in marginal field development in Nigeria. With a doctrinal research methodology consisting of analyses of laws, policies, principles and practices, and a slight comparative study of Nigeria with Malaysia and Angola, the research discovers that marginal field operations, because of its peculiar circumstances, require special tax incentives, which are currently inexistent or ineffective in Nigeria. Taking useful lessons from Malaysia and Angola, the paper proposes a special tax regime for marginal field operations comprising exclusive tax and royalty rates, and other incentives to be backed up by statutory law.

Keywords: marginal fields, tax incentives, petroleum industry, development

\section{Introduction}

Tax is a compulsory levy imposed by the government on the citizenry through specific enactments to facilitate economic development. It is one of the sources of income for government. It can also be defined as "a charge imposed by governmental authority upon property, individuals or transactions to raise money for public purposes.ii Blacks Law Dictionary describes tax as "a monetary charge imposed by the government on people, entities, transactions or property to yield public revenue. It includes duties, imports and excises." ${ }^{\prime i i}$

Tax incentives are the various tax standards, rates and regulatory modes created by law to encourage and motivate investment in a sector. Tax systems the world over are geared towards achieving specific economic objectives of government and encouraging persons in taxable activities. Thus an important factor in deciding to invest in a country is the structure of the tax system and its favorableness to the business. Tax incentives are therefore, flexible instruments in laws, policies and contracts that lessen tax burdens for categories of persons or businesses. These incentives are usually provided in the laws in the form of tax reliefs and holidays, allowances and deductions for the benefit of the particular taxpayers targeted by them.

To achieve the noble objective of encouraging persons in taxable activities through tax incentives, a tax system must be made compatible with what Adam Smith in the Wealth of Nationsiv called the "maxims of a good tax system" These maxims are:

- Equity: According to Adam Smith, while subjects of a state ought to contribute to the support of their government through tax, such contributions should as nearly as possible be proportionate to their respective abilities.v

- Certainty: The certainty principle demands that the amount of tax expected to be paid as well as the time and manner of payment should be exact and clear so that businesses can plan properly. This is to prevent arbitrariness and uncertainty, which encourages the corruption of men.

- Convenience: By the principle of convenience, every tax ought to be levied at the time or manner in which it is most likely to be convenient for the contributor to pay. For example, a tax system is convenient if taxes are collected at the time revenues or payments are received by taxpayers.

- Administrative Efficiency: This principle states that the cost of administering a tax -assessment and collection etc. should be as far as possible, very minimal so that returns on tax will be commensurate with the reason for imposition.

In the military era in Nigeria, tax incentives were usually created through decrees, budget speeches, government notices and directives, and executed agreements. Under democracy, the strongest guarantee of a tax incentive is through statutory law. 


\section{Tax Regime and the Controversy of a Tax Rate for Marginal Fields in Nigeria:}

The indigenous companies producing some of the 24 marginal fields awarded by the federal government in 2003 reached an agreement with the Federal Government on a flat petroleum profit tax rate of 55 percent as against the general rate of 85 percent in the Petroleum Profit Tax Act. This agreement meant to encourage the companies that benefitted from the awards and hasten their progress to production stage however turned out to be a mere gentleman's agreement, as there was neither a formal binding contract nor a statutory enactment to back it up. The government only issued letters to the companies approving the agreed tax rate. Unsurprisingly, the companies were later faced with the brick wall while seeking implementation of this tax rate by the Federal Inland Revenue Service (FIRS) vi

This plight of the marginal field operators can be easily understood. Tax is strictly a subject of statutory law and not of contract or compromise, as held in the case of Shell Petroleum International MATTTSC GAPPIJ BIV v. Federal Board of Inland Revenue.vii

None of the tax legislations in Nigeria has any specific provisions on marginal field operations. Neither does any of the laws have any special rate of tax applying exclusively to marginal fields. Attempts have however been made to create special tax regimes for marginal fields, but in the absence of legislative instruments backing up such attempts, they have so far proved unhelpful to the marginal field operators. For instance, in 2005, the then President, Olusegun Obasanjo, in his capacity as the Minister for Petroleum Resources, introduced the Marginal Fields Operations (Fiscal Regime) Regulations. The Regulations stipulated the following royalty rates as applicable to Marginal Field Operations:

\begin{tabular}{|c|c|c|}
\hline S/ No & Production Range (bopd) & Royalty Rate (\%) \\
\hline 1 & below 5000 & 2.5 \\
\hline 2 & 5000 bopd $-10,000$ & 7.5 \\
\hline 3 & 10,000 bopd $-15,000$ & 12.5 \\
\hline 4 & 15,000 bopd $-25,000$ & 18.5 \\
\hline
\end{tabular}

Table 1: Royalty Rates for Marginal Fields

Source: Marginal Fields Operations (Fiscal Regime) Regulations S.I. No. 82006

Obasanjo as Petroleum Minister, made the above Regulations pursuant to section 9(1) of the Petroleum Act, which empowers the Minister to make regulations, prescribing anything requiring to be prescribed for the purposes of the Act, inter alia. While this established preferential royalty rates for marginal fields, it did not stipulate the rate at which assessable tax on chargeable profits from marginal field operations would be charged.

Apparently as a complement to the above Regulations, the DPR issued a letter of 12th July 2006 outlining the following as "revised fiscal terms for Marginal fields" as approved by Government in Nigeria: Petroleum Profit Tax (PPT) rate of 55\%, Investment Tax Allowance of 20\%; Royalty rates in tranches of 2.5\%, 7.5\%, 12.5\%, 18.5\% for production rates of 5,000bopd, 5,000 - 10,000bopd, 10,000 - 15,000bopd and 15,000 to 25,000bopd; and Co-mingled production from two or more reservoir with compatibility of reservoir fluids and pressures.

But in the clear absence of a law creating or enabling any exclusive tax treatment for marginal fields, FIRS is reluctant to apply any purported tax incentive instrument. FIRS recognizes and applies the royalty rates in the Marginal Fields Operations (Fiscal Regime) Regulations stated above, for the clear reasons that: firstly, royalty rates, unlike tax is enabled by administrative regulations, although the enabling regulation must itself be enabled by statutory law, and the regulation in this case is enabled by section 9(1) of the Petroleum Act; secondly, the above-mentioned letter of 12th July 2006 which was made available to FIRS states that the specified royalty rates in the 2005 Regulations, as restated, were gazetted in gazette number 21 of April 5, 2006. But in the case of the 55\% tax rate, FIRS has to date, bluntly refused to apply that, for lack of statutory enablement, as a mere letter cannot take the place of a law .

Section 21 of the Petroleum Profit Tax Act provides a tax rate of $65.75 \%$, and this gave birth to another raging controversy concerning the taxation of marginal fields. The law provides this reduced rate for the benefit of all oil companies (not just marginal fields) in their pre-production stage. FIRS battles to clear the erroneous impression of the marginal field operators that this $65.75 \%$ PPT rate is a permanent tax rate for them. FIRS maintains that this rate only applies to any upstream company whether or not a marginal field operator, unless and until a change in the law makes it special and permanent for the marginal field.

\section{Petroleum Tax Incentives that Avail Marginal Fields in Nigeria}

Lack of special tax incentives for marginal fields as discussed above places the fields under the incentives in the general laws which apply to all oil and gas companies including the IOCs. An additional issue of concern is that even these general tax incentives are lost in obscurity or so hidden in the laws that only the most diligent companies identify and exploit them. Diligence in this context lies in affording thoroughbred tax consultants of high repute who pore through the tax laws to detect favorable openings for their clients; and tax specialist law firms who defend their clients' stance in court. Most of the marginal field operators are not financially advantaged to afford either of these. Even for the IOCs that are better off, most incentive provisions in the laws are fraught with ambiguities thus leading to frequent interpretative issues that draw both the taxpayers and FIRS into protracted litigation. Hence, even when such matters are resolved in favour of the companies, the costs of litigation and consultancy services take much substance out of the secured incentive. 
The following are some of the general incentives available for marginal fields.

\subsection{Tax Deductible Expenses}

The commonest and most substantial tax incentive for petroleum companies is tax deductible expenses. Tax law provides that in ascertaining chargeable tax, certain deductions are made which are excluded from the computed tax. The deductions are all expenses and outgoings wholly, exclusively, necessarily incurred in the production of the income of the fiscal year. Under the PPTA, deductible expenses and outgoings begins with section 9 whereby adjusted profits are arrived at after deductions under sections $10 \& 20$ of that Act. Section 10 deductions are all outgoings and expenses wholly, exclusively and necessarily incurred whether within Nigeria or without for the purpose of petroleum operations including rents in respect of lands or buildings occupied in the course of the OPL and OML.

The Section 10 incentives are far-reaching. Judicial interpretation further expounded and also seem to have expanded its ambit, such that whatever expense that passes the test of having been incurred "wholly", "exclusively", and "necessarily" for petroleum operations, popularly known as the WENTest, qualifies for tax exemption under section 10. A classic instance of the wide and liberal interpretation of the WEN Test was in Shell Petroleum Development Company v. Federal Board of Inland Revenueviii where the Supreme Court applied the test to exempt from tax, Central Bank charges and commissions incurred by Shell in the course of sourcing for foreign currencies to pay its tax, and also scholarship expenses.

\subsection{Petroleum Investment Allowance and Annual Allowance}

These are allowances that make up for qualifying capital expenditure (QCE) which a company incurs on its assets. Their relationship to tax is that if a company has claimed all the QCE it incurred on an asset in the form of allowances over a period, and later sells the asset and still realizes from the sale, an amount equal to the QCE which it had already recovered through the allowance, then it must bring the sales proceeds to tax as balancing charge. Even when there is outstanding QCE which had not been recovered through the allowances, part of the sales proceeds on the asset equal to the outstanding QCE would go to the company while the excess proceeds would go to tax as balancing charge. But when there is outstanding QCE and the sales proceeds is not up to it, the company would be entitled to an allowance known as balancing allowance which is equal to the remainder of the QCE beyond what is covered by the sales proceeds. This formula was for computation of Realizable Price as the Posted Price of crude oil pursuant to Section 23(3) and (5) of the PPTA. The formula is replicated in Clause 2.4 of the 2000 MOU. Paragraphs 5 of the $2^{\text {nd }}$ Schedule to the PPTA provides for Petroleum Investment Allowance, while Paragraph 6(1) of the same $2^{\text {nd }}$ Schedule to the PPTA provides for annual allowance. These two allowances are employed for the same purpose. They are both claimed on an asset upon which QCE has been incurred, in order to offset the QCE. The only difference between the two is that PIA is due only once on an asset; that is "in the accounting period in which that asset was first used" as stated in Paragraph 5(1) above, whereas AA is due on annual basis "as from the accounting period in which such expenditure was incurred" as stated in Paragraph 6(1) above. Both allowances are incentives to encourage acquisition and use of assets for petroleum development. They are both available to marginal field operators.

\subsection{Incentive against Double Taxation under Section 60 of PPTA}

Section 60 of the PPTA provides as follows,

"No tax shall be charged under the provisions of the Personal Income Tax Act or any other Act in respect of any income or dividends paid out of any profits which are taken into account, under the provisions of this Act, in the calculation of the amount of any chargeable profits upon which tax is charged, assessed, and paid under this Act."

The words, "...any profits which are taken into account, under the provisions of this Act, in the calculation of the amount of any chargeable profits upon which tax is charged, assessed, and paid under this Act" in the above-quoted section 60 PPTA clearly refer to profits which are taxed under the PPTA. The essence of that provision is to prevent a situation of double taxation where an income or profit that has suffered a form of taxation, e.g. withholding tax under the PPTA would still be brought under tax in the Personal Income Tax Act or any other law. Therefore, section 60 applies to such incomes and profits suffering tax under PPTA of which there is no other provision of the PPTA that has moved them to PITA or to another law for taxation. In the absence of such other provision in respect of such incomes, they stand the risk of double taxation. It is to resolve this perceived risk of double jeopardy that section 60 became necessary. Section 60 requires that an income or dividend which would benefit from that provision must be one that is taken into account in the calculation of the amount of any chargeable profits upon which tax is charged, assessed, and paid under the PPTA. Section 9 (1) which provides for the profits of a company under the PPTA provides that the profits of that period of a company shall be taken to be the aggregate of "... all income of the company of that period incidental to and arising from any one or more of its petroleum operations." All such incomes as are referred to in Section 9(1) ® above, would benefit from the incentive in section 60.

\subsection{Pioneer Status}

Pioneer status is a tax incentive that is meant to give a company a preferred position in getting established. In granting a company pioneer status the industry or product is regarded as one that is not already carried on in the country or the existing industry is not producing enough to meet the current or expected requirements. The concept is further broadened to include any industry or product for which there is a favourable prospect of development. 
The law governing the operations of the pioneer companies is the Industrial Development (Income Tax Relief) Act CAP I7 Laws of the Federation of Nigeria, 2004. The Act, provides that where the Nigerian government is of the opinion that any sector or industry in the economy is not being undertaken on a scale suitable to the economic advancement of Nigeria or that it is in the public interest to encourage the further development or establishment or advancement of trade in such sector or industry, the President of Nigeria is authorized to publish in a Gazette, a list of such industries to who qualify for pioneer status. ix

Apparently in response to the clarion calls for the inclusion of marginal fields in the list of pioneer industries, ${ }^{\mathrm{x}}$ the NIPC started granting pioneer status certificates to some marginal field companies, albeit in terms and manner akin to setting the cart before the horse. The pioneer status certificates granted included petroleum profit tax contrary to the scope of the Industrial Development Act. Two examples can be presented here, namely, the pioneer status granted to Energia Limited in respect of the Obodugwa/ Obodeti Marginal Field in December, 2011, xi and that granted to Midwestern Oil and Gas Company Limited in respect of the Umusadege Marginal Field in October, 2011 xii This has stirred up two contentious issues: whether it is right to grant pioneer status to marginal fields which are taxed under the Petroleum Profit Tax Act without first amending the Industrial Development Act (IDA); and what is the rightful tenure of the pioneer status.

Pioneer status is limited to Companies Income Tax, and does not apply to Petroleum Profit Tax. This is clearly indicated in the Industrial Development Act by its copious reference to the Companies Income Tax Act as "the principal Act." In fact, Section 25 of the IDA buttresses this point by expressly defining "principal Act" to mean the Companies Income Tax Act Cap. C21; defining "production day" as the day on which the trade or business of a pioneer company commences for the purposes of the principal Act, i.e. CITA; and also stating unequivocally that "qualifying capital expenditure", a key factor in determining income tax, means capital expenditure of such a nature as to rank as qualifying expenditure for the purposes of the Second Schedule to the principal Act, i.e. CITA.

Generally, pioneer status is granted for an initial term of three years and two subsequent renewals of one year each, or a single renewal of two years, totaling five years. Thus Section 10 of the IDA provides as follows:

- The tax relief period of a pioneer company shall commence on the date of the production day of the company, and subject to sections 3 (6) and of 7 (2) of this Act, the tax relief period shall continue for three years.

- The tax relief period of a pioneer company may at the end of the three years be extended by the President-

$>$ for a period of one year and thereafter for another period of one year commencing from

the end of the first period of extension; or

$>$ for one period of two years."

Section 10 restated above is made subject to sections 3(6) and 7(2) of this Act. Sections 3(6) creates an exception to the above terms in section 10 in the case of a company that has acquired or proposes to acquire assets from any company to which a pioneer certificate has been granted under the Aid to Pioneer Industries Act, or the IDA; or a company that has taken over or proposes to take over the whole assets of any other company which is not a pioneer company. For either of these two categories of companies, the pioneer certificate to be granted may specify a maximum tax relief period, not exceeding five years.

It is settled law, and indeed a trite principle of statutory interpretation that when a particular section of a statute is made subject to another section, the effect thereof is to subordinate and conform the first-mentioned section to the secondmentioned section. In other words, the section made subject to the other must bow and give way whenever that other seeks passage. This principle is illustrated in the famous case of NDIC v. Okem Enterprises. xiii The effect of this principle vis-à-vis the relationship between sections 10 and 3(6) of the IDA is that it is left for a marginal field company to establish that it has acquired or proposes to acquire assets from any company to which a pioneer certificate has been granted under the Aid to Pioneer Industries Act, or the IDA; or that it has taken over or proposes to take over the whole assets of any other company which is not a pioneer company, then such a marginal field company would be entitled to the five-year term under section 3(6) of IDA, notwithstanding section 10.

Almost at the end of the five years of pioneer status granted to Energia and Midwestern Oil, NIPC issued subsequent letters retroactively reviewing the terms downwards to three years at the first instance. FIRS, in a swift response, raised tax assessments on the companies for the period outside the three years of the reviewed grant. This expectedly opened a floodgate of litigations wherein suits were commenced by the aggrieved marginal field operators at the Tax Appeal Tribunal established pursuant to section 59 of the Federal Inland Revenue Service Establishment Act, 2007 to settle disputes arising from the operations of the tax laws. These suits seek to challenge the tax assessments raised pursuant to the review of their pioneer status. ${ }^{\text {iiv }}$

Lessons from the foregoing on pioneer status is that the ideal step to establish utmost availability of pioneer status as a tax incentive for the marginal field companies by the government would be to amend the IDA in order to create a strong room for petroleum profit tax in the pioneer status incentive. In respect of the tenure of a pioneer status, it must be established to the expressed satisfaction of NIPC that a marginal field company falls under the categories for a five-year pioneer status under section 3(6) before same would be granted to such a company, otherwise the company should be placed under the general class of initial three-year pioneer status in section 10. This would help in avoiding protracted litigations involving marginal field companies, NIPC, FIRS and other relevant bodies over review of an earlier pioneer status. The demerit 
of litigations in terms of monetary cost, distraction for the companies, and uncertainty of tax position, makes nonsense of the purported tax relief in the pioneer status.

\section{Lessons from Malaysia and Angola}

Malaysia has a special tax model for marginal fields. The tax model consists of three key Regulations on tax incentive introduced in 2013 but made retroactive to 2010. With these Regulations, Malaysia, unlike Nigeria created tax incentives that are exclusive to the marginal field companies in that country. These regulations are subsidiary legislations, namely: Petroleum (Income Tax) (Exemption) Order 2013 (Exemption Order) [P.U. (A) 122]; Petroleum (Income Tax) (Accelerated Capital Allowances) (Marginal Field) Rules 2013 (ACA Rules) [P.U. (A) 119]; and Petroleum (Income Tax) (Investment Allowance) Regulations 2013 (IA Regulations) [P.U.(A) 120].

Angola also has special and exclusive legislation for the development of its marginal fields. Angola took a legislative step in the direction of marginal field development which gives it the edge over Nigeria. In March, 2016, a law was passed by the Angolan parliament authorizing the country's president to adopt new incentives and adjust the contractual and fiscal terms for marginal fields. A parliamentarian Maria Julia Ornelas stated that the aim of this law was to stimulate investment in developing marginal discoveries, rather than keeping the country's petroleum wealth in the ground.xv

Pursuant to this legislative authorization granted by Law No. 4/ 16, of 17 May 2016, the President of the Republic of Angola enacted the authorized Presidential Legislative Decree No. 2/16, of 13 June 2016 ("PLD 2/16"), establishing the "Procedure and Incentives for the Adjustment of the Contractual and Fiscal Terms Applicable to Concessions Including Marginal Discoveries". PLD 2/16 provides incentives for the adjustment of the contractual and fiscal terms applicable to marginal discoveries. The guiding principle of this provision is Tolerance and Contractual Flexibility'. With this provision, marginal fields under contractual arrangements can easily be adjusted to match changing circumstances and meet the need for rapid development.

The fiscal incentives comprise the following: (i) the rates for Petroleum Production Tax and Petroleum Income Tax and the percentage of Investment Allowance for PIT purposes and of Production Bonus, are to be determined by reference to the volume of recoverable resources; (ii) the amortization period for capital expenditures varies between 2 and 4 years, depending on the volume of recoverable resources; (iii) the assessment of PIT only becomes required as of the third, fourth or fifth year of amortization of capital expenditures, at percentages depending on the volume of recoverable resources; (iv) the period for recovery of development expenses will be determined between 2 and 4 years, based on the volume of recoverable resources; (v) a full exemption of customs charges and duties on petroleum exports is to be granted for a 5-year period from commencement of commercial production.

The key lesson from Angola and Malaysia is the need to acknowledge and treat marginal fields as an industry in its special class when it comes to taxation and incentives. It bears repeating that the relevant laws in Nigeria has no special treatment for marginal fields. But Angola, just like Malaysia recognized the inadequacy of the general incentives of the petroleum industry for marginal fields, and hence proceeded to create a system of laws to encourage investment in marginal fields. It is the undue subsuming of marginal fields in the general laws of the Nigerian petroleum industry that resulted in lack of special tax treatment for marginal fields, and insecurity of the few granted incentives like pioneer status. A special law for marginal field taxation would underscore the special status of marginal fields and secure the provided incentives.

Malaysia offers an additional clue to Nigeria, namely, that the creation of tax incentives exclusive to marginal fields can be achieved through subsidiary legislations. Nigeria must not wait for the rigorous process of new laws like the passage of the Petroleum Industry Governance Bill or amendment of extant Acts of the National Assembly before adjusting the rates of taxation as exclusive incentives to marginal fields. If the Federal Government of Nigeria, through the DPR, NNPC, Petroleum Minister and President(who in fact currently doubles as both) can proffer regulations on incentives for marginal fields, such can be annexed to the extant tax laws as subsidiary legislations.

\section{Recommendations}

A novel area of investment requires a distinct legal framework. Marginal fields are relatively costly to develop, requires much of unconventional technology, and with low oil reserves. Tax incentive is therefore one of the surest means of encouraging investment in such fields. Hence, a special legislation is recommended here, which would create a special tax rate and other tax incentives for marginal fields. Petroleum operations in the deep offshore and inland basin zone also faced with such stiff peculiar challenges, received legislative attention in 1993 with the enactment of the Deep Offshore and Inland Basin (Production Sharing Contracts) Act of that year Section 3(1) of the Deep Offshore Act provides for a tax rate of $50 \%$ of chargeable profit as against the $85 \%$ rate in the PPTA. In setting the royalty rates for the deep offshore zones, the law takes into cognizance the depth of each discovery. In this order, the deeper the oil discovery, the lower the royalty, and vice-versa, which is referred to as graduated royalty rate.

As an alternative to an exclusive legislation for marginal field taxation, the existing tax laws can be amended to create special tax incentives for marginal fields in consideration of their peculiar circumstances. The recognition of marginal field existence, and their mode of acquisition and operation were all enabled by amendment of the Petroleum Act. Even the Petroleum Profit Tax Act was amended at some point to move the taxation of gas operations from the PPTA where the tax rate 
is $85 \%$, to the Companies Income Tax Act with a much lower tax rate of $30 \%$, as one of the incentives to encourage gas utilization, and consequently alleviate gas flaring.

A special tax regime can also be created for marginal fields by contractual means in the form of memorandum of understanding (MOU) between the Government and the marginal field operating companies. MOU is usually a legal arrangement or agreement between the Government and oil companies for the creation of incentives for the latter. The MOU in taxation generally guarantees incentive of less tax so that companies are doing business under a perfect certainty of profit. The formulae and factors applicable are usually settled between the Ministry of Finance on behalf the Federal Government and the companies.

A clear indication that the IOC-Government MOU is essentially a tax incentive document can be deduced from the heading of the 2000 MOU between the Federal Government of Nigeria and Total Exploration and Production Nigeria Limited which goes as follows: "Memorandum Of Understanding On Incentives For Encouraging Investments In Exploration And Development Activities And Enhancing Crude Oil Exports" As an incentive document, this MOU seeks to add to or improve on the general incentives in the PPTA. The PPTA guided tax accounting practices of petroleum operating companies until a novel change was developed in the early 70s when the production of much oil in the international market caused a reduction in the price of oil and the profits of oil and gas companies. This slump in the oil market eroded oil companies' profit margins and led to a decline in oil and gas development activities in Nigeria. To manage this economic reality, the country resorted to some remedial measures to encourage these companies to continually explore and produce oil and gas by guaranteeing to them a minimum profit margin per barrel of oil produced. The resort to MOUs was to encourage more investment in the oil business for greater revenue for the country. The 1986 MOU was revised in 1991 for another period of 5 years with certain amendments to include reserve and additional bonuses. This amendment was necessitated by a high rate of inflation that overtook the profit margin. The last MOU was signed in 2000. In giving statutory background and enablement to the MOUs, Sections 9 (2)(a), and 23(3) of the Petroleum Profit Tax Act ("PPTA") contemplate an agreement between the Federal Government of Nigeria and an upstream petroleum company in determining the Petroleum Profit Tax and Education Tax liabilities of a company.

\section{Conclusion}

Marginal fields constitute a new investment area in the petroleum industry, but many peculiar challenges discourage investment in this area. These challenges which include low oil and gas reserves, unconventional technology, and funding incapacity of the indigenous investors to whom the fields are exclusively granted, call for special tax incentives. Marginal field special tax regimes in Malaysia and Angola present good examples to Nigeria. The tax incentive regime for marginal fields in Nigeria can be achieved by enactment of a special law for marginal fields, amendment of the extant laws to create special incentives for the marginal fields, or through MOU.

\footnotetext{
7. References

i. $\quad$ Farayola, G. O. (1987) Guide to Nigerian Taxes. Lagos: All Crowns Nigeria Ltd.p.3.

ii. Hopkins, J. (2000) New Webster's Dictionary of the English Language College Edition. India: Surjeet Publications.p.1574.

iii. $\quad$ Garner, B. (2004) Black's Law Dictionary 8th ed. New York: Thompson West. p.1496.

iv. Smith, A. (2003) Wealth of Nations. New York: Bantam Dell, p 1042.

v. Duru, N. (2006, February 12). Applicable Tax Rates Must Be Competitive. This Day, p.10.

vi. Alike, E. (2014, April 1). Marginal Field Operators Groan under Harsh Tax Regimes. Thisday.

vii. (2011) 4 TLRN 97.

viii. $\quad$ (1996) 8 NWLR (Pt. 446) 256.

ix. Section 1 of the Industrial Development (Income Tax Relief) Act.

x. 10 Alatoye, A. (2015, August 29). Pioneer Status Incentive to Indigenous, Marginal Field Operators is in the Right Direction. Thisday.

xi. $\quad$ NIPC letter to Energia dated 22nd December, 2011 with Ref. No. NIPC/ INC/ 622/ Vol. 1, obtained on March 28, 2017.

xii. NIPC letter to Midwestern Oil dated 21st October, 2011 with Ref. No. NIPC/ INC/ 610/Vol. 1, obtained on March 28, 2017.

xiii. $\quad$ (2004) 10 NWLR (Pt. 880) 107 at 183.

xiv. See Suit No: TAT/LZ/ PPT/012/2015 between Midwestern Oil \& Gas Co. Ltd. v. FIRS and Suit No: TAT/ LZ/ PPT/ 003/ 2017 between Energia Ltd. v. FIRS, both pending at the Tax Appeal Tribunal, Lagos.

xv. Angola: Parliament approves marginal discoveries project

xvi. http:/ / www.portalangop.co.ao/ angola/ en us/ noticias/ politica/ 2016/ 2/ 13/ Angola-Parliament-approves-marginaldiscoveries-project,c85574ec-b31b-4306-8̄e0f-ab766bf72419.html accessed on May 12, 2016.
} 